\title{
Postnatal Changes in the Chemical Heterogeneity of Human Fetal Hemoglobin
}

\author{
W. A. Schroeder ${ }^{[41]}$, T. H. J. Huisman, Audrey K. Brown, Romeo Uy ${ }^{[39]}$, Nicole G. Bouver, \\ P. O. Lerch, J. Roger Shelton, Joan Balog Shelton, and Gerald Apell \\ Division of Chemistry and Chemical Engincering, California Institute of Technology, Pasadena, California, \\ Veterans Administration Hospital, Laboratory of Protein Chemistry, and Department of Pediatrics, \\ Medical College of Georgia, Augusta, Georgia, USA
}

\begin{abstract}
Extract
The fetal hemoglobin ( $\mathrm{Hb}-\mathrm{F})$ of blood samples from 11 newborn babies (two normal infants, two sickle cell trait carriers, two Hb-G heterozygotes, two infants with $\mathrm{Hb}-\mathrm{SC}$ disease, one infant with $\mathrm{Hb}$-Richmond heterozygosity, one $\beta$-thalassemia heterozygote, and one infant with a heterozygosity for the hereditary persistence of fetal hemoglobin) and from 16 adults (eight normals, two $\mathrm{Hb}-\mathrm{S}$ heterozygotes, one $\mathrm{Hb}-\mathrm{C}$ heterozygote, and five $\mathrm{SC}$ patients) has been examined to determine the ratio of the two structurally different $\gamma$ chains, namely the ${ }^{\mathrm{G}} \gamma$ and ${ }^{\mathrm{A}} \gamma$ chains. This ratio is about $2: 3$ in the $\mathrm{Hb}-\mathrm{F}$ of the adults and, therefore, significantly different from the $3: 1$ ratio in the $\mathrm{Hb}-\mathrm{F}$ of the newborn. This newborn ratio undergoes a considerable change between the 3rd and 4th months of life, at which time it approaches that of the $\mathrm{Hb}-\mathrm{F}$ of adults.
\end{abstract}

\section{Speculation}

The mechanism by which the gradual change from $\gamma$ chain synthesis to $\beta$ and $\delta$ chain synthesis is controlled remains unclear. However, the change in the ratio of production of structurally different $\gamma$ chains as a function of postnatal age indicates a rather complex mechanism which probably involves an unequal repression of the $\gamma$ chain structural genes. Any explanation of the mechanism must take into account the fact that the production of two genes, the ${ }^{\mathrm{c}} \gamma$ and ${ }^{\mathrm{s}} \gamma$, is greatly decreased, whereas that of two other genes, the $\beta$ and $\delta$, is started. Perhaps a closely related or even identical mechanism controls not only the ratio of production of the ${ }^{\mathrm{G}} \gamma$ and ${ }^{\mathrm{A}} \gamma$ genes but also that of the $\beta$ and $\delta$ genes.

\section{Introduction}

Fetal hemoglobin (H)-F or $\alpha_{2} \gamma_{2}$ ) constitutes $50-90 \%$ of the total hemoglobin with an average value of about $75 \%$ in cord blood samples from full-term newborn infants [25]. The gradual replacement of $\mathrm{Hb}-\mathrm{F}$ by aclult hemoglobins $A\left(\alpha_{2} \beta_{2}\right)$ and $\Lambda_{2}\left(\alpha_{2} \delta_{2}\right)$ is essentially complete 150 days after birth $[12,32]$, although levels of $1-3 \%$ are observed during the first 3 years of life [23].

In the hemoglobin of normal adults, the alkali-resistant residue is $0.4-1.0 \%$ [23]. Although this residue may not be $\mathrm{Hb}-\mathrm{F}$ alone $[10,22]$, it is generally assumed to contain variable amounts of the same $\mathrm{Hb}$-F that is present in cord blood $[10,13,15,26]$. However, appre- 
ciable amounts of $\mathrm{Hb}-\mathrm{F}$ can be detected in the peripheral blood of individuals 6 months of age and older who have an acquired hematologic disorder or a genetic abnormality, such as $\beta$-thalassemia or a hemoglobinopathy $[3,4,6,7,11,31]$.

In a previous communication [29], we presented evidence that Hb-F of the newborn human infant is a chromatographically and electrophoretically inseparable mixture of two components that differ in the $\gamma$ chains. In one type of $\gamma$ chain (the " $\gamma$ type [35]) a glycyl residue is present in position 136, whereas in the other (the ${ }^{\Delta} \gamma$ type) an alanyl residue is present in this position. The ratio of $\mathrm{c}_{\gamma}$ to ${ }^{\mathrm{A}} \gamma$ chains in newborn $\mathrm{Hb}-\mathrm{F}$ is about $3: 1$. Examination of $\mathrm{Hb}-\mathrm{F}$ variants, abnormal in the $\gamma$ chain, and of the Hb-F from individuals with hereditary persistence of fetal hemoglobin established that the ${ }^{\circ} \gamma$ and ${ }^{\Delta} \gamma$ chains are the products of nonallelic structural genes for the $\gamma$ chain [18-20, 29].

The question arises whether the 3:1 ratio of the ${ }^{a_{\gamma}}$ and ${ }^{A} \gamma$ chains in the Hb-F of the newborn infant remains constant during carly postnatal life and is the same in the minute amount of $\mathrm{Hb}-\mathrm{F}$ found in adult blood. The pattern of this ratio was investigated by serial examination of $\mathrm{Hb}-\mathrm{F}$ from infants in the lst year of life and by analysis of $\mathrm{Hb}-\mathrm{F}$ from normal adults and several patients with hemoglobinopathies. Some of these data have been described in a preliminary report [27].

\section{Materials and Methods}

\section{Source of Blood Samples}

Nine full-term Negro infants were studied at intervals during the lst year of life. Two subjects had sickle cell trait, two were heterozygous for $\mathrm{Hb}-\mathrm{C}$, one was doubly heterozygous for hemoglobins $S$ and $\mathrm{C}$, one was heterozygous for Hb-Richmond [9], one was a heterozygous $\beta$-thalassemia carrier, one was heterozygous for the hereditary persistence of fetal hemoglobin, and one was normal. One normal infant and one with $\mathrm{Hb}$ SC disease were studied only once. Blood samples (2-4 $\mathrm{ml}$ increasing to $5-15 \mathrm{ml}$ at 5 months of age or older) were collected in ethylenediaminetetraacetate (EDTA).

Samples of blood, $250-500 \mathrm{ml}$, from three normal adult females, from two adult sickle cell carriers, and from one adult $\mathrm{Hb}$-C trait carrier were collected in acid-citrate-dextrose (ACD). A few milliliters of blood were also placed in EDTA for hematologic analyses. Smaller volumes (50-100 $\mathrm{ml}$ in EDTA) were obtained from other adults: two Caucasian individuals from one family with slightly elevated Hb-F percentage [24], three members of a Negro family with a comparable elevation of $\mathrm{Hb}-\mathrm{F} \mathrm{[14]}$, and five patients with $\mathrm{Hb}-\mathrm{SC}$ clisease [38].

\section{Hematologic Examination and Hemoglobin Analysis}

Hemoglobin concentration (in $\mathrm{g} / 100 \mathrm{ml}$ ), packed cell volume (PCV in percent), red cell (in $10^{6} / \mathrm{mm}^{3}$ ), and reticulocyte counts (in percent) were determined by standard techniques [33].

Red cell hemolysates were studied by starch gel electrophoresis in Tris-EDTA-boric acid buffer, $\mathrm{pH} 8.1$ [16], and by DEAE-Sephadex chromatography [8, 17]. The latter procedure allows the quantitation of relative amounts of hemoglobins $A_{2}, A$ (and/or $S$ and $C$ ), and $F$ in the hemolysates. Quantitation of $\mathrm{Hb}-\mathrm{F}$ involved alkali denaturation [5] and a recently developed method [30]. Data obtained with these two techniques are presented as $\% \mathrm{~F}_{\mathrm{AD}}$ and $\% \mathrm{~F}_{1 \mathrm{le}}$, respectively [30]. Comparative studies have shown that the $\mathrm{F}_{\text {ne }}$ data are probably more reliable [30].

\section{Isolation of Hb-F for Chemical Examination}

Column chromatography on DEAE-Sephadex was also used for the isolation of larger amounts of Hb-F. The $\mathrm{Hb}-\mathrm{A}_{1}+\mathrm{F}$ fractions from several preparative columns $(2.5$ by $50 \mathrm{~cm})$ were combined and rechromatographed in the same way to remove residual $\mathrm{Hb}-\mathrm{A}_{0}$. The relative amount of $\mathrm{Hb}-\mathrm{F}$ in these purified $\mathrm{A}_{\mathbf{1}}+\mathrm{F}$ fractions varied greatly; rechromatography on a cation exchange resin was made when the $\mathrm{Hb}-\mathrm{F}$ was estimated to be less than $15 \%$. For this purpose the $A_{1}+F$ fraction was applied to a column $(3.0$ by $35 \mathrm{~cm}$ ) of CM-cellulose [36] which was equilibrated with 0.01 ir sodium phosphate buffer, $\mathrm{pH}$ 6.8. The chromatogram was developed with a $\mathrm{pH}$ gradient $(0.01 \mathrm{M}$ sodium phosphate buffers of pH 6.8, 7.2, 7.4, 7.6, and 7.8 with $100 \mathrm{mg} \mathrm{KCN} / 100 \mathrm{ml}$ ) as previously described [17]. The $\mathrm{Hb}-\mathrm{A}_{1}$ fraction was eluted from the column as a broad heterogeneous zone that was followed by a small, rather homogeneous, zone primarily of $\mathrm{Hb}-\mathrm{F}$. The appropriate hemoglobin fractions were converted into globin by the procedure of Anson and Mirsky [1].

\section{Chemical Examination of $\mathrm{Hb}-\mathrm{F}$}

Investigation of the globins of the isolated $\mathrm{Hb}-\mathrm{F}$ components was made as previously described [29]; the globin was cleaved with cyanogen bromide and the smallest peptide, $\gamma \mathrm{CB}-3$, was isolated and analyzed. The minimal amount of fetal globin for a single analy. 
Table I. Hematologic data on blood samples from infants 1 day-14 months of age, and the results of chemical analyses of $\mathrm{Hb}-\mathrm{F}$ isolated from these samples

\begin{tabular}{|c|c|c|c|c|c|c|c|c|c|c|c|c|}
\hline \multirow{3}{*}{ Case } & \multirow{3}{*}{$\begin{array}{c}\text { Race and } \\
\text { sex }^{1}\end{array}$} & \multirow{3}{*}{ Hb typez } & \multirow{3}{*}{ Age, days } & \multirow{3}{*}{$\begin{array}{l}\mathrm{Hb}, \\
\mathrm{g} / 100 \mathrm{ml}\end{array}$} & \multirow{3}{*}{ PCV, $\%$} & \multirow{3}{*}{$\begin{array}{c}\mathrm{RBC}, \\
10^{0} / \mathrm{mm}^{3}\end{array}$} & \multirow{3}{*}{$\begin{array}{c}\text { Retic., } \\
\%\end{array}$} & \multirow{3}{*}{$\underset{\%}{\mathrm{Ilb}_{\%} \mathrm{~A}_{2},}$} & \multicolumn{2}{|c|}{$\mathrm{H} \mathrm{b}-\mathrm{F}^{\mathrm{a}}$} & \multicolumn{2}{|c|}{$\gamma \mathrm{CB}-3$} \\
\hline & & & & & & & & & $\mathrm{AD}$ & Ile & Gly & Ala \\
\hline & & & & & & & & & & & & \\
\hline \multirow[t]{2}{*}{$C G$} & N-F & $\mathbf{A A}$ & 1 & 18.6 & 50 & 5.07 & n.d.t & $<0.1$ & n.d. & $(88.9)$ & 0.72 & 2.33 \\
\hline & & & 200 & 9.5 & 32 & 3.03 & 0.3 & 2.1 & 3.4 & 4.8 & 0.57 & 2.50 \\
\hline ko & $\mathrm{N} \cdot \mathrm{MI}$ & $\mathrm{AA}$ & 270 & n.d. & n.d. & 4.05 & n.d. & 2.4 & 1.8 & n.d. & 0.42 & 2.69 \\
\hline \multirow[t]{8}{*}{$S T$} & $N \cdot F$ & $\mathbf{A S}$ & 1 & 17.1 & 51 & 5.48 & n.d. & $<0.1$ & n.d. & $(84.1)$ & 0.71 & 2.34 \\
\hline & & & 30 & 10.2 & 33 & 3.00 & 1.5 & 0.4 & n.d. & 61.8 & 0.68 & 2.37 \\
\hline & & & 112 & 9.4 & 31 & 3.69 & 0.6 & 2.6 & 11.7 & 14.3 & 0.47 & 2.52 \\
\hline & & & 156 & 10.0 & 30 & 4.15 & 0.7 & 3.4 & 5.9 & 6.3 & 0.40 & 2.62 \\
\hline & & & 197 & 11.0 & 33 & 4.19 & 2.1 & 3.6 & 3.8 & 4.5 & 0.39 & 2.67 \\
\hline & & & 253 & 10.4 & 31 & 4.09 & 0.5 & 3.1 & 3.4 & 2.8 & 0.44 & 2.65 \\
\hline & & & 318 & 10.6 & 31 & 3.98 & 0.7 & 2.8 & 3.1 & 2.0 & 0.33 & 2.73 \\
\hline & & & 373 & 11.2 & 34 & 4.32 & 0.9 & 2.8 & 2.2 & 1.5 & 0.33 & 2.85 \\
\hline \multirow[t]{5}{*}{$M W$} & $\mathbf{N}-\mathbf{M}$ & AS & 1 & n.d. & n.d. & n.d. & n.d. & $<0.1$ & n.d. & $(86.4)$ & 0.72 & 2.34 \\
\hline & & & 35 & 13.4 & 40 & 3.51 & 1.1 & $<0.1$ & n.d. & 71.5 & 0.71 & 2.42 \\
\hline & & & 65 & 9.1 & 30 & 2.99 & n.d. & 0.6 & 48.3 & 62.9 & 0.71 & 2.32 \\
\hline & & & 183 & 11.0 & 35 & 3.42 & n.d. & 2.8 & 5.6 & 8.4 & 0.52 & 2.49 \\
\hline & & & 336 & 9.4 & 30 & 4.18 & 3.2 & 2.8 & 3.4 & 2.7 & 0.39 & 2.66 \\
\hline \multirow[t]{2}{*}{$A J$} & $N \cdot M I$ & $\Lambda \mathrm{C}$ & 60 & 10.2 & 30 & 3.75 & 6.4 & -6 & 20.3 & 23.5 & 0.57 & 2.45 \\
\hline & & & 101 & 12.5 & 34 & 4.46 & 1.9 & - & n.d. & 9.1 & 0.48 & 2.53 \\
\hline \multirow[t]{9}{*}{$C B$} & N-F & $\mathrm{AC}$ & 14 & n.d. & n.d. & n.d. & n.d. & - & n.d. & $(86.9)$ & 0.69 & 2.35 \\
\hline & & & 28 & 11.2 & 38 & 3.37 & 0.3 & - & n.d. & $(79.2)$ & 0.66 & 2.38 \\
\hline & & & 56 & 10.7 & 33 & 4.01 & n.d. & - & n.d. & $(50.1)$ & 0.66 & 2.42 \\
\hline & & & 84 & n.d. & n.d. & n.d. & n.d. & - & n.d. & 19.3 & 0.55 & 2.49 \\
\hline & & & 120 & 11.3 & 30 & 4.41 & n.d. & - & n.d. & 9.2 & 0.49 & 2.60 \\
\hline & & & 150 & 11.1 & 28 & 3.95 & n.d. & - & 4.4 & 3.8 & 0.39 & 2.61 \\
\hline & & & 210 & 8.8 & 29 & 4.30 & n.d. & - & n.d. & 3.4 & 0.38 & 2.70 \\
\hline & & & 255 & 9.3 & 28 & 4.03 & 1.1 & - & n.d. & 3.8 & 0.41 & 2.68 \\
\hline & & & 300 & 8.5 & 26 & 3.94 & n.d. & - & 1.6 & 2.5 & 0.30 & 2.78 \\
\hline \multirow[t]{7}{*}{$K J$} & $\mathrm{~N} \cdot \mathrm{MI}$ & SC & 1 & 18.6 & 52 & 5.43 & n.d. & - & n.d. & $(89.8)$ & 0.71 & 2.35 \\
\hline & & & 51 & 9.6 & 30 & 3.28 & n.d. & - & n.d. & $(58.7)$ & 0.64 & 2.34 \\
\hline & & & 114 & 8.6 & 27 & 3.10 & 6.2 & - & n.d. & 14.4 & 0.56 & 2.48 \\
\hline & & & 184 & 8.8 & 28 & 3.33 & n.d. & - & 7.4 & 7.0 & 0.48 & 2.63 \\
\hline & & & 262 & 10.4 & 33 & 3.53 & n.d. & - & 4.1 & 4.5 & 0.45 & 2.59 \\
\hline & & & 317 & 9.5 & 30 & 3.49 & 3.6 & - & 3.5 & 2.9 & 0.58 & 2.54 \\
\hline & & & 409 & 9.7 & 28 & 4.30 & 1.2 & - & 2.8 & n.d. & 0.50 & 2.57 \\
\hline$T H$ & $\mathrm{~N}-\mathrm{M}$ & sc & 650 & 10.5 & 31 & 4.73 & 1.1 & - & 14.5 & 19.4 & 0.57 & 2.51 \\
\hline$A S$ & N-F & A.Rich. & 1 & 13.2 & 44 & 3.20 & 3.6 & $<0.1$ & 42.9 & 70.5 & 0.72 & 2.30 \\
\hline & & & 53 & 10.4 & 32 & 3.19 & 2.2 & 1.2 & 38.5 & 43.0 & 0.68 & 2.35 \\
\hline & & & 127 & 10.8 & 32 & 3.60 & 0.6 & 4.4 & 6.1 & 6.7 & 0.48 & 2.57 \\
\hline$R S$ & $N \cdot F$ & A. $\beta$ Th. & 56 & 10.6 & 31 & 4.24 & n.d. & 2.9 & n.d. & 29.9 & 0.56 & 2.54 \\
\hline & & & 117 & 11.4 & 37 & 3.67 & n.d. & 4.5 & 4.1 & 4.8 & 0.45 & 2.62 \\
\hline & & & 146 & 11.4 & 36 & 3.98 & n.d. & 3.9 & n.d. & 2.5 & 0.42 & 2.70 \\
\hline & & & 439 & 9.7 & 32 & 5.30 & 1.8 & 4.4 & 1.6 & 1.6 & 0.30 & 2.72 \\
\hline$R B$ & N.F & A-IIPFII & 1 & n.d. & n.d. & n.d. & n.d. & 0 & 59.3 & 87.2 & 0.67 & 2.29 \\
\hline & & & 63 & 11.8 & 34 & 4.00 & 1.2 & 0.5 & 51.0 & 66.3 & 0.66 & 2.40 \\
\hline & & & 91 & 13.2 & 39 & 4.57 & 1.2 & 1.5 & n.d. & 43.7 & 0.62 & 2.38 \\
\hline & & & 127 & 11.2 & 36 & 3.92 & 1.2 & 1.2 & 34.4 & 38.8 & 0.58 & 2.38 \\
\hline & & & 157 & - & - & - & - & 1.3 & 30.9 & 35.4 & 0.58 & 2.49 \\
\hline & & & 190 & 12.8 & 38 & 5.25 & 0.5 & 1.6 & 30.7 & 36.7 & 0.55 & 2.45 \\
\hline & & & 203 & 11.8 & 37 & 4.23 & 0.7 & 1.3 & 31.4 & 31.8 & 0.58 & 2.43 \\
\hline
\end{tabular}

I N : Negro; F: female; $M$ : male

Sce Mfaterials and Methods for definition of hemoglobin types.

- Percentages of $1 \mathrm{~b}$-F in parentheses were determined by DEAE-Sephadex chromatography only [8, 17$]$; such values usually agree with $\% F_{I 10}$ values if the percent $11 \mathrm{~b} \cdot \mathrm{F}$ is large.

n.d., not determined.

- $1 \mathrm{~b}$ - $A_{2}$ was not determined because the hemoglobins $C$ and $A_{2}$ are eluted together from columns of DEAE-Sephadex [8, 17]. 
Table II. Hematologic data on blood samples from adult subjects, and the results of chemical analyses of Hb-F isolated from these samples

\begin{tabular}{|c|c|c|c|c|c|c|c|c|c|c|c|c|}
\hline \multirow{3}{*}{ Case } & \multirow{3}{*}{$\begin{array}{l}\text { Race and } \\
\text { sex }^{1}\end{array}$} & \multirow{3}{*}{ Ilb type 2} & \multirow{3}{*}{ Age, yr } & \multirow{3}{*}{$\begin{array}{l}\mathrm{Hb} \\
\mathrm{g} / 100 \mathrm{ml}\end{array}$} & \multirow{3}{*}{ PCV, \% } & \multirow{3}{*}{$\underset{10^{6} / \mathrm{mm}^{2}}{\mathrm{RBC}}$} & \multirow{3}{*}{ Retic., \% } & \multirow{3}{*}{$\mathrm{Hb}-\mathrm{A}_{\mathbf{2}}, \%$} & \multicolumn{2}{|c|}{$\mathrm{Hb}-\mathrm{F}$} & \multirow{2}{*}{\multicolumn{2}{|c|}{$\gamma \mathrm{CB}-3$}} \\
\hline & & & & & & & & & AD & Ile & & \\
\hline & & & & & & & & & \multicolumn{2}{|c|}{$\%$} & Gly & A1a \\
\hline$A D$ & C.F & $\begin{array}{c}\text { AA, } \\
\text { 2nd sample }\end{array}$ & 38 & 13.3 & 40 & 4.36 & 0.6 & 2.8 & 0.9 & n.d. & $\begin{array}{l}0.51 \\
0.44\end{array}$ & $\begin{array}{l}2.59 \\
2.67\end{array}$ \\
\hline$N B$ & C.F & $\mathrm{AA}$ & 25 & 11.7 & 40 & 4.10 & n.d. & 2.7 & 1.0 & n.d. & 0.23 & 2.99 \\
\hline$G D$ & $\mathbf{N} \cdot \mathbf{F}$ & $A A$ & 30 & n.d. & n.d. & n.d. & n.d. & 2.4 & 0.9 & n.d. & 0.29 & 2.80 \\
\hline$I F$ & C-F & $\mathbf{A A}$ & 30 & 15.1 & 49 & 4.47 & 0.9 & 2.5 & 1.2 & n.d. & 0.55 & 2.52 \\
\hline$L L$ & C-M & $\mathbf{A A}$ & 27 & 16.0 & 54 & 4.84 & 0.4 & 2.7 & 1.4 & n.d. & 0.55 & 2.52 \\
\hline$S R$ & $\mathrm{~N}-\mathrm{M}$ & $\mathbf{A A}$ & 43 & 14.2 & 50 & 4.98 & 0.8 & 2.8 & 1.4 & 0.8 & 0.37 & 2.67 \\
\hline$E R$ & N-F & $\mathbf{A A}$ & 12 & 11.3 & 39 & 3.90 & 2.0 & 3.2 & 1.9 & 1.3 & 0.31 & 2.73 \\
\hline$R R$ & $\mathbf{N} \cdot \mathbf{M}$ & $\mathrm{AA}$ & 10 & 11.6 & 38 & 4.19 & 1.4 & 3.4 & 1.8 & 1.0 & 0.25 & 2.82 \\
\hline$J M I$ & $\mathrm{~N}-\mathrm{M}$ & AS & 26 & n.d. & n.d. & n.d. & n.d. & 3.4 & 0.8 & 0.9 & 0.65 & 2.33 \\
\hline$M T$ & N-F & AS & 30 & 11.4 & 34 & 3.87 & 0.9 & 3.3 & 0.9 & 0.6 & 0.36 & 2.72 \\
\hline$A B$ & N-F & $\wedge \mathrm{C}$ & 28 & 13.6 & 39 & 5.48 & 1.1 & -5 & 1.5 & 1.3 & 0.47 & 2.57 \\
\hline WC & $\mathrm{N}-\mathrm{M}$ & SC & 24 & 14.6 & 45 & 4.93 & 4.2 & 一 & 1.4 & n.d. & 0.48 & 2.64 \\
\hline$J J$ & N-M & $\mathrm{SC}$ & 14 & 11.3 & 34 & 4.37 & n.d. & - & 5.4 & 4.7 & 0.45 & 2.58 \\
\hline $\mathrm{HO}$ & N-M & SC & 31 & 11.9 & 37 & 3.84 & 1.1 & 一 & 2.4 & 2.4 & 0.66 & 2.42 \\
\hline$M I R$ & $\mathrm{~N} \cdot \mathrm{F}$ & $\mathrm{SC}$ & 60 & 9.3 & 29 & 3.00 & 5.4 & - & 2.6 & 2.1 & 0.36 & 2.59 \\
\hline$A R$ & N-F & $\mathrm{SC}$ & 23 & 8.2 & 28 & 2.50 & 8.3 & - & 7.3 & - & 0.38 & 2.65 \\
\hline
\end{tabular}

1 C: Caucasian; N: Negro; F : female; $M$ : male.

See Materials and Methods for definition of hemoglobin types.

n.d., not determined.

- This analysis was made on globin prepared from the alkali-resistant hemoglobin fraction. Red cell hemolys te from about $250 \mathrm{ml}$ blood was treated with alkali [31]. The soluble fraction was dialyzed overnight against running tap water and concentrated on a 8 by $20 \mathrm{~cm}$ column of CM-Sephadex in $0.05 \mathrm{M}$ Tris-maleic acid, pH 6.5 [37], from which it was eluted with $0.1 \mathrm{M}$ Tris- $\mathrm{HCl}, \mathrm{pH} 8.0$.

${ }_{5} \mathrm{Hb}-\mathrm{A}_{2}$ was not determined because the hemoglobins $\mathrm{C}$ and $A_{2}$ are eluted together from columns of DEAE-Sephadex [8, 17].
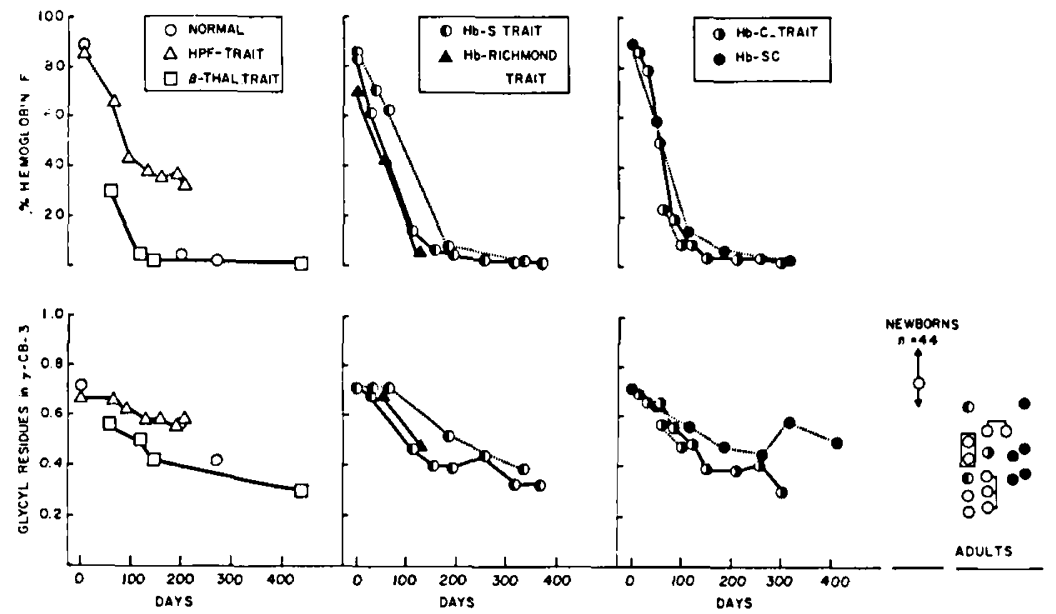

Fig. 1. Postnatal changes in the \% Hb-F and the number of glycyl residues of the $\gamma \mathrm{CB}-3$ peptide of Hb-F from normal newborns and newborns with different hemoglobin abnormalities. Sce text and Tables I and II for further details.

als in one of two groups: in group 1 , the ratio of $\mathrm{s}_{\gamma}$ to ${ }^{A} \gamma$ chains is about $2: 3$ as in the adult, whereas in group $I I$ it is about $3: 1$ as in the newborn [28]. Baby $R S$ obviously belongs in group $I$. There is convincing evidence that this ratio is an inheritable characteristic in $\beta$-thalassemia. This could not be tested in this family because attempts to isolate a sufficient quantity of
Hb-F from the blood of the mother of baby RS who is also heterozygous for $\beta$-thalassemia were unsuccessful. Baby $R B$ is the child of $R E$ (family $E$ in Table IA [19]) who is an HPFH heterozygote with about $25 \%$ $\mathrm{F}_{\text {Ile. }}$ The ${ }^{\mathrm{G}} \gamma$ to ${ }^{\mathrm{A}_{\gamma}}$ ratio in the $\mathrm{Hb}-\mathrm{F}$ from the mother and three members of this family was about $3: 2$ and probably was different from the approxi- 
mately $2: 3$ ratio in the $\mathrm{Hb}-\mathrm{F}$ of most $\mathrm{HPFH}$ heterozygotes [19]. The $\mathrm{Hb}-\mathrm{F}$ of infant $R B$ descreased in about 150 days to the rather constant level of $35 \%$, and a ${ }^{\mathrm{G}} \gamma$ to ${ }^{\Delta} \gamma$ ratio of $3: 2$ was reached at about the same time. It is also of interest that the glycine value in the $\mathrm{Hb}-\mathrm{F}$ of the cord blood sample ( 0.67 residue) is in the lower part of the newborn range. This observation can be explained by assuming that at birth the $\gamma$ chain loci in cis to the HPFH determinant produce ${ }^{\mathrm{G}_{\gamma}}$ and ${ }^{\boldsymbol{A}_{\gamma}}$ chains in a ratio of about $3: 2$ and those in trans produce these chains in the newborn ratio of about $3: 1$.

The orderly appearance and disappearance of fetal and adult forms of hemoglobin are probably the most obvious and best known examples of the regulation and control of protein synthesis and provide an excellent opportunity to study the genetic mechanisms involved. Although hypothetical explanations of the switch from $\mathrm{Hb}-\mathrm{F}$ to $\mathrm{Hb}-\mathrm{A}$, or more precisely from $\gamma$ to $\beta$ and $\delta$ chains, have been advanced $[2,21,34]$, insight into this mechanism is lacking. Our data add little to the understanding of this mechanism except to show a complexity greater than previously realized, because the evidence clearly suggests an unequal repression of the ${ }^{b_{\gamma}}$ and ${ }^{A_{\gamma}}$ structural genes as the switchover occurs. The determination of the ratio of ${ }^{\mathrm{G}} \gamma$ to ${ }^{\mathrm{A}} \gamma$, however, does allow an examination of the functioning of the switchover mechanism. Studies of Hb-F in $\beta$-thalassemia, for instance, suggest [28] that in one type it is partially inoperative whereas in another, as in the case of baby $R S$, it is fully functional. This is indicated by the fact that $\mathrm{Hb}-\mathrm{F}$ in $\beta$-thalassemia heterozygotes is not elevated over normal in both groups that have been detected [28]. Because all hypothetical explanations of the switchover mechanism were published prior to the detection of the two types of $\gamma$ chain, they could not take into account the presence of the nonallelic genes as any future explanation must do. One may well consicler whether or not the eventual explanation for the control of the ratio of $\mathrm{G}_{\gamma}$ to ${ }^{\mathrm{A}} \gamma$ chains and the change from $3: 1$ in the newborn infant to $2: 3$ in the adult may not also give the answer to the oft-asked question "Why are the $\beta$ and $\delta$ chains normally in the ratio of 40 to 1?" We must appreciate that, in switching from the production of $\gamma$ to $\beta$ and $\delta$ chains, we actually are switching from the production of two genes, ${ }^{a} \gamma$ and ${ }^{A} \gamma$, to that of two other genes, $\beta$ and $\delta$. Is the factor that gives a ratio of $3: 1 \mathrm{c}_{\gamma}$ to ${ }^{{ }} \gamma$ chains in the prenatal state the same as or related to that which controls the ratio of $40: 1 \beta$ to $\delta$ chains in the postnatal state? The present data do not really answer this question, but it may be possible to draw pertinent conclusions as more is learned about the ratio of the ${ }^{{ }^{G}} \gamma$ to ${ }^{A} \gamma$ chains in those instances in which $\mathrm{Hb}-\mathrm{F}$ is elevated in adult life.

\section{Summary}

The fetal hemoglobin (Hb-F) of blood samples from 11 newborn babies and from 16 adults was examined to determine the ratio of the two structurally different $\gamma$ chains, namely the ${ }^{G} \gamma$ and ${ }^{A} \gamma$ chains. This ratio is about 2:3 in the Hb-F of adults and, therefore, significantly different from the 3:1 ratio in the Hb-F found in newborns. The newborn ratio, however, undergoes a considerable change between the 3rd and 4th months of life, at which time it approaches that of the $\mathrm{Hb}$-F of adults.

The mechanism by which the gradual change from $\gamma$ chain synthesis to $\beta$ and $\delta$ chain synthesis is controlled remains unclear and probably involves an unequal repression of the $\gamma$ chain structural genes. Any explanation of the mechanism must take into account the fact that the production of two genes, the ${ }^{G} \gamma$ and ${ }^{A} \gamma$, is greatly clecreased, whereas that of two other genes, the $\beta$ and $\delta$, is started. Perhaps a closely related or even identical mechanism controls not only the ratio of production of the ${ }^{\mathrm{a}} \gamma$ and ${ }^{\mathrm{A}} \gamma$ genes but also that of the $\beta$ and $\delta$ genes.

\section{References and Notes}

1. Anson, M. S., ANd Mirsky, A. E.: Protein coagulation and its reversal. The preparation of insoluble globin and heme. J. Gen. Physiol., 13: 468 (1930).

2. Baclioni, C.: Correlations between genetics and chemistry of human hemoglobins. In: J. H. Taylor: Molecular Genetics, Part 1 (Academic Press, New York, 1963).

3. Beaven, G. H., Ellis, M. J., ANd White, J. C.: Studies on human foetal haemoglobin. II. Foctal haemoglobin levels in healthly children and adults and in certain haematological disorders. Brit. J. Hacmat., 6: 201 (1960).

4. Beaven, G. H., Ellis, M. J., ANd White, J. C.: Studics on human foetal haemoglobin. III. The hereditary haemoglobi. nopathies and thalassaemias. Brit. J. Hacmat., 7: 169 (1961).

5. BetKe, K., Marti, H., and Schlicilt, I.: Estimation of small percentages of foctal hacmoglobin. Nature, 184: 1877 (1959).

6. BertLes, J. E.: The occurrence and significance of foctal hemoglobins. In: A. S. Gordon: Regulation of Hematopoiesis (Appleton-Century-Crofts, New York, 1969).

7. BiCKERS, J. N.: Alkali-resistant hemoglobin in sickle-cell discase. Ann. Intern. Med., 6t: 1628 (1966).

8. Dozy, A. M., Klemhauer, E. F., and Huisman, T. H. J.: Studies on the heterogeneity of hemoglobin. XIII. Chromatography of various human and animal hemoglobin types on DEAE. Sephadex. J. Chromatogr., 32: 723 (1968).

9. Efremov, G. D., Huisman, T. H. J., Smith, L. L., Wilson, J. B., Kitchens, J. L., Wrightstone, R. N., AND AdAMs, H. R.: 
Hemoglobin Richmond, a human hemoglobin which forms asymmetric hybrids with other hemoglobins. J. Biol. Chem., 2tt: $6105(1969)$.

10. Fabliz-liansen, I.: The composition of the alkali-resistant haemoglobin fraction in blood from normal human adults. Brit. J. Haemat., 7: 187 (1961).

11. Farrar, J. F., AND Blomfifi.d, F.: Alkali-resistant haemoglobin content of blood in congenital heart disease. Brit. J. Haemat., 9: $278(1963)$.

19. Gakb3Y, L., SJölin, S., AND Vullue, J. C.: Studies on erythrokinetics in infancy. II. The relative rate of synthesis of haemoglobin $\mathrm{F}$ and haemoglobin $A$ during the first months of life. Acta Pacdiat., 51: 245 (1962).

13. Hall, J. G., and Motulsky, A. G.: Production of foetal hacmoglobin in marrow cultures of human adults. Nature, 217: 569 (1968).

14. Horton, B. F., Hahn, D. A., and Huisman, T. H. J.: Slight increase of fetal hemoglobin in apparently healthy Negroes. Acta Haemat., 33: 312 (1965).

15. Huisnan, T. H. J., Jonxis, J. H. P., and Dozy, A. M.: Is foetal hacmoglobin present in the blood of normal human adults? Biochim. Biophys. Acta, 18: 576 (1955).

16. Huisman, T. H. J.: Normal and abnormal human hemoglobins. Advan. Clin. Chem., 6: 231 (1963).

17. Huisman, T. H. J., ANo Dozy, A. M.: Studies on the heterogeneity of hemoglobin. IX. The use of tris(hydroxymethyl) aminomethane-HCl buffers in the anion exchange chromatography of hemoglobins. J. Chromatogr., 19: 160 (1965).

18. Huisman, T. H. J., Schroeder, W. A., Adans, H. R., Shrteton, J. R., Shilton, J. B., and Apell, G.: A possible subclass of the hereditary persistence of fetal hemoglobin. Blood, 36 : l (1970).

19. Huisman, T. H. J., Schroeder, W. A., Dozy, A. M., Shelton, J, R., Siflton, J. B., Boyd, E. M., ANd Apell, G.: Evidence for multiple structural genes for the $\gamma$ chain of human fetal hemoglobin in hereditary persistence of fetal hemoglobin. Ann. N. Y. Acall. Sci., 165: 320 (1969).

20. Huisman, T. H. J., Schroeder, W. A., Stamatoyannopoulos, G., Bouver, N., Shelton, J. R., Shelton, J. B., ANd Apell, G.: Nature of fetal hemoglobin in the Greck type of herelitary persistence of fetal hemoglobin with and without concurrent $\beta$-thalassemia. J. Clin. Invest., 49: 1035 (1970).

21. INGRAM, V. M.: A molecular model for thalarsemia. Anm. N. Y. Acad. Sci., 119: 485 (1963).

22. Jonxis, J. H. P., ANd Huisman, T. H. J.: The detection and estimation of fetal hemoglobin by means of the alkali denaturation test. Blood, 11: 1009 (1956).

23. Kleihauer, E. F.: Fetales Hämoglobin und fetale Erythrozyten (Ferdinand Enke Verlag, Stuttgart, 1966).

24. MARTI, H. R., AND Bürter, R.: Hämoglobin F und hämoglobin $A_{2}$-Vermehrung bei der schweizer bevölkerung. Acta Haemat., 26: 65 (1961).

25. Oski, F. A., And Naman, J. L.: Hematologic Problems in the Newborn (W. B. Saunders Co., Philadelphia, 1966).

26. Rucknaget, D. L., ANd Ghernoff, A. I.: Immunologic studies of hemoglobins. III. Fetal hemoglobin changes in the circulation of pregnant women. Blood, 10: 1092 (1955).
27. Schrofider, W. A., and Huisman, T. H. J.: Investigations of molecular variation in human fetal hemoglobin in the infant and in certain hematological conditions in the adult. In: H. Pecters: Procedings of the 17th Colloquium on Protides of the Biological Fluids, p. 249 (Bruges, 1970).

28. Schrofdf, W. A., Huisman, T. H. J., Shelton, J. R., SilelTON, J. B., Apell, G., AND Bouver, N.: Heterogeneity of fetal hemoglobin in $\beta$-thalassemia of the Negro. Amer. J. Hum. Genet., 22: 505 (1970).

99. Schrofder, W. A., Huisman, T. H. J., Shelton, J. R., Shelton, J. B., Klemauer, E. F., Dozy, A. M., and Robbersox, B.: Evidence for multiple structural genes for the $\gamma$ chain of human fetal hemoglobin. Proc. Nat. Acad. Sci. U. S. A., 60: 537 (1968)

30. Schrofifr, W. A., Hulsman, T. H. J., Shelton, J. R., And W'ilson, J. B.: An improved method for the quantitative determination of human fetal hemoglobin. Anal. Biochem., 35: $235(1970)$.

31. Singtr, K., Chervofy, A. I., And Singer, L.: Studies on abnormal hemoglobins. I. Their demonstration in sickle cell ancmia and other hematological clisorders by means of alkali denaturation. Blood, 6: 113 (1951).

32. Wilson, M. G., Schrofdfr, W. A., Graves, I). A., ANd Kach, V. D.: Hemoglobin variation in D-trisomy syndrome. New Engl. J. Med., 277: 953 (1968).

33. Wintrobe, M. M.: Clinical Itematology, ed. 5 (Lea and Febiger, Philadelphia, 1962.)

34. 7uckerkande, E.: Controller-gene diseases: the operon model as applied to $\beta$-thalassemia, familial fetal hemoglobinemia, and the normal switch from the production of the fetal hemoglobin to that of adult hemoglobins. J. Mol. Biol., $s$ : 128 (1964).

35. The terminology of these chains which formerly [29] were designated the $\gamma^{136015}$ or $\gamma^{G}$ chains and the $\gamma^{130 \Lambda 1 a}$ or $\gamma^{\Lambda}$ chains has recently been modified [20].

36. Whatman microgranular CM-52, preswollen, ion capacity 1.0 $m \mathrm{Eq} / \mathrm{g}$ dry weight, Reeve Angel Co., New York, N. Y.

37. CM-Sephadex, C-50, capacity $4.5 \pm 0.5 \mathrm{mEq} / \mathrm{g}$, particle size 40-120 $\mu$, Pharmacia Fine Chemicals, Inc., Piscataway, N. J.

38. Informed consent was obtained for all subjects in this study.

39. This paper is in memory of our dedicated co-worker and friend, Dr. Romeo Uy, who was murdered on March 9, 1970.

40. Supported by Public Health Service Research Grants no. HE. 02558, HE-05168, and HD-02800. The authors are indebted to Dr. H. R. Marti (Switzerland) who made blood samples from subjects IF and $L L$ available, and to Dr. G. Stamatoyannopoulos (Seattle, Wash.) who supplied the samples from the two fetuses. This is contribution 4103 from the Division of Chemistry and Chemical Engineering, California Institute of Technology, Pasadena, Calif.

41. Requests for reprints should be addressed to: W. A. Scuroedre, Division of Chemistry and Chemical Engineering, California Institute of Technology, 1201 East California Boulevard, Pasadena, Calif. 91109 (USA).

42. Accepted for publication November 25, 1970. 